\title{
PEMIKIRAN PSIKOLOGI ISLAM DALAM IMPLIKASI PENDIDIKAN SOSIAL
}

\author{
ADNAN \\ Jurusan Manajemen Dakwah Fakultas Dakwah dan Komunikasi \\ Universitas Islam Negeri Alauddin Makassar \\ Email : Adnan22@gmail.com.
}

\begin{abstract}
Abstrak
Pengembangan pemikiran psikologis dalam latar belakang dunia Islam kontemporer oleh sains dan teknologi gerakan Islamisasi. Gelombang ini menyapu seluruh wilayah, termasuk Muslim Indonesia. Khususnya di Indonesia, dekade terakhir di antara psikolog Muslim Indonesia muncul di psikologi wacana Islam. Munculnya psikologi wacana Islam dapat dilihat dari dua sisi. Di satu sisi, ini merupakan indikasi pengaruh gelombang dan semangat islamisasi sains dan teknologi yang sudah mulai muncul sejak 1980-an. Di sisi lain, merupakan cerminan dari kesadaran sebagian besar psikolog Muslim Indonesia yang mulai memahami keterbatasan psikologi dalam menjelaskan realitas eksistensi manusia dalam pleno. Antusiasme terhadap munculnya Psikologi Islam mendorong penerapan berbagai simposium, seminar, dan penerbitan buku tentang psikologi Islam. Tetapi gerakan ini masih bersifat periferial, meskipun harus diakui bahwa wacana-wacana ini telah menimbulkan masalah mendasar, atau dengan kata lain, beberapa psikolog Muslim Indonesia mulai dengan sungguh-sungguh menyadari keterbatasan teori-teori psikologis yang telah ditetapkan dalam mengekspresikan eksistensi manusia yang nyata. Maka dari itu perlu dilakukan kajian alternatif dalam membahas manusia. Untuk mewujudkan hal ini, tentu bukan tidak mungkin meski tanpa kendala. Beberapa faktor penghambat utama adalah sikap psikolog Muslim yang tidak seragam, yaitu: apatis, fanatik, sekuler, dan antagonis idealis. Faktor penghambat lainnya adalah ketertarikan psikolog Muslim sebagian dengan teori-teori yang telah ditetapkan dan dikembangkan yang tidak berasal dari Islam.
\end{abstract}

Kata kunci: Psikologi Islam, Pendidikan Sosial

\begin{abstract}
Development of psychological thought in the contemporary Islamic world background by Islamization movement science and technology. This wave is sweeping across the region, including Indonesia Muslims. Particularly in Indonesia, recent decades among Indonesian Muslim psychologists appear on the psychology of Islamic discourse. The emergence of Islamic discourse psychology can be viewed from two sides. On the one hand, this is an indication of the influence of the waves and the spirit of Islamization of science and technology that have started to emerge since the 1980s. On the other hand, is a reflection of the consciousness of most Indonesian Muslim
\end{abstract}


psychologists are beginning to understand the limitations of psychology in explaining the reality of human existence in the plenary. Enthusiasm for the emergence of Islamic Psychology encourages the implementation of various symposia, seminars, and publishing a book on the psychology of Islam. But this movement is still periferial, although it should be recognized that these discourses have led to fundamental problems, or in other words, some psychologists Muslim Indonesia began in earnest to realize the limitations of psychological theories that have been established in expressing real human existence. Thus the need to conduct a study of alternatives in discussing human. To realize this, of course not impossible though not without obstacles. Some of the main inhibiting factor is the attitude of Muslim psychologists are not uniform, namely: apathy, fanatical, secularists, and idealistic antagonist. Other inhibiting factors are partially psychologist Muslim fascination with theories that have been established and developed that does not come from Islam.

Keywords: Psychological of Islamic, social-education

\section{PENDAHULUAN}

Dilatarbelakangi oleh kejatuhan dunia Islam dalam cengkeraman penjajahan Eropah dan Barat dan selanjutnya berada di bawah pengaruh budaya sekular Eropah dan Barat sehingga banyak Ilmuwan Muslim yang tergila-gila terhadap segala aspek peradaban Eropa dan Barat termasuk teori-teori Psikologi. Akibatnya adalah keterputusan rantai antara ahli psikologi Muslim modern dengan warisan psikologi kelasik Islam. Ini dapat dilihat dari kenyataan - yang sangat patut disayangkan - bahwa para ahli psikologi Muslim yang mendalami psikologi dari Barat umumnya memulai kajian psikologi pada kaum pemikir Yunani, terutama Plato dan Aristoteles. Selanjutnya, mereka langsung membahas pemikiran kejiwaan para pemikir Eropah abad pertengahan dan Masa Kebangkitan (Renaisance) Eropah Modern. Mereka benar-benar melupakan andil para ilmuwan Muslim yang di antaranya banyak diterjemahkan ke dalam bahasa Latin dan banyak mempengaruhi pendapat para pemikir Eropah abad pertengahan hingga awal masa renaisans Eropah Modern sendiri. Yang lebih menyedihkan lagi, sikap para sejarahwan psikologi dari Barat tersebut justru diikuti oleh para pakar psikologi Muslim kontemporer. Mereka yang mempelajari berbagai manuskrip sejarah psikologi di banyak universitas sama sekali tidak melirik peranan para ilmuwan Muslim. Penghargaan terhadap andil mereka justru datang dari para sejarahwan filsafat Islam, baik yang berasal dari bangsa Arab sendiri maupun non Arab. Mereka menginformasikan kepada kita 
sejumlah ikhtisar yang bermanfaat tentang pandangan para ilmuwan Muslim terdahulu dalam bidang psikologi. Kendati nilainya sangat penting, namun ikhtisar tersebut tidak cukup menarik minat para psikolog Muslim kontemporer untuk mendalami pandangan kejiwaan yang dibangun oleh para pendahulunya.

Jurnal ini membahas tentang pemikiran psikologi dalam perkembangan pemikiran Islam dengan memfokuskan pembahasan pada latar belakang kemunculan pemikiran psikologi dalam khazanah pemikiran Islam yang kemudian dilanjutkan dengan perkembangan diskursus paradigma psikologi dalam Islam guna memberikan gambaran pada pembaca tentang apa yang berlangsung saat ini dalam pemikiran Islam dalam bidang psikologi ini. Pada bagian tokoh psikologi dipaparkan sebagian tokoh-tokoh ilmuwan Muslim masa kelasik beserta sekilas teorinya yang memberikan kontribusi penting dalam perkembangan bidang psikologi. Bagian ini kemudian mengetengahkan tokoh psikologi dan pecinta psikologi Islam kontemporer beserta karya-karyanya guna memberikan optimisme pada pembaca akan kemungkinan tumbuh dan berkembangnya kembali bangunan-bangunan bidang psikologi yang Islami. Pembahasan kemudian diikuti dengan implikasi pemikiran psikologi dalam dunia Islam untuk memberikan gambaran terkini pada pemikiran psikologi dalam dunia Islam. Bagian penutup merupakan bagian yang mengingatkan kepada semua umat Islam untuk tetap optimis dan membangun kerjasama dalam mewujudkan kembali psikologi Islam.

Akhirnya, tulisan ini diharapkan dapat menjadi rujukan ringan dalam menyemai, memupuk, menumbuhkan dan memetik hasil kerja dalam bidang psikologi Islam yang dinanti-nantikan produksinya bukan saja oleh kalangan Muslim, namun oleh semua

manusia yang ingin jati diri kemanusiaanya sempurna pertumbuhan dan perkembangannya.

\section{KAJIAN PUSTAKA}

\section{Latar Belakang Pemikiran Psikologi dalam Islam}

Menapak-tilasi latar belakang kajian psikologi dalam Islam dilakukan pertama sekali dengan menelusuri ayat-ayat Al-Qur'an dan Hadis yang memotivasi manusia untuk mengkaji dirinya sendiri yang antara lain adalah: 


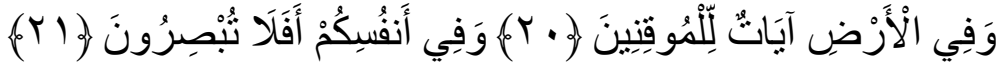

Terjemahnya:

Dan di bumi itu terdapat tanda-tanda (kekuasaan Allah) bagi orang-orang yang yakin. Dan (juga) pada dirimu sendiri, maka apakah kamu tiada memperhatikan? (QS. Al-Dzariat/51: 20-21)

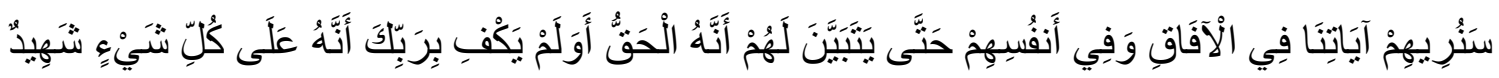

Terjemahnya:

Kami akan memperlihatkan kepada mereka tanda-tanda (kekuasaan) Kami di segenap ufuk dan pada diri mereka sendiri, sehingga jelaslah bagi mereka bahwa Al Qur'an itu adalah benar. Dan apakah Tuhanmu tidak cukup (bagi kamu) bahwa sesungguhnya Dia menyaksikan segala sesuatu? (QS. Fuşilat/41: 53)

Termasuk dalam hal ini mengkaji sisi psikologis manusia.

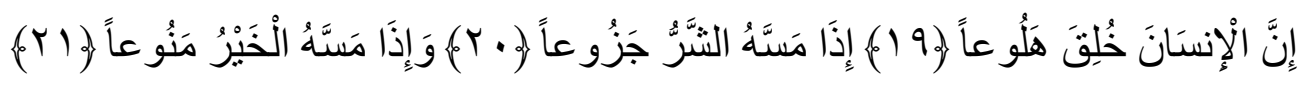

Terjemahnya:

Sesungguhnya manusia diciptakan bersifat keluh kesah lagi kikir. Apabila ia ditimpa kesusahan ia berkeluh kesah. Dan apabila ia mendapat kebaikan ia amat kikir. (QS. 70/Al-Ma’ârij: 19-21)

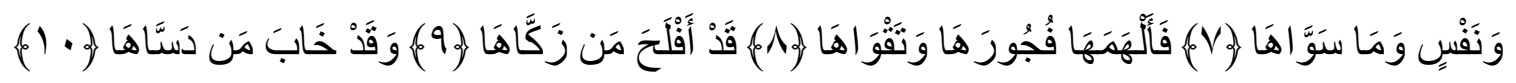

Terjemahnya:

Dan jiwa serta penyempurnaannya (ciptaannya). Maka Allah mengilhamkan kepada jiwa itu (jalan) kefasikan dan ketakwaannya. Sesungguhnya beruntunglah orang yang mensucikan jiwa itu. Dan sesungguhnya merugilah orang yang mengotorinya. (QS. 91/Al-Syams: 7-10)

Demikian juga hadis-hadis Rasulullah saw. banyak bermuatan tentang kejiwaan manusia yang antara lain adalah:

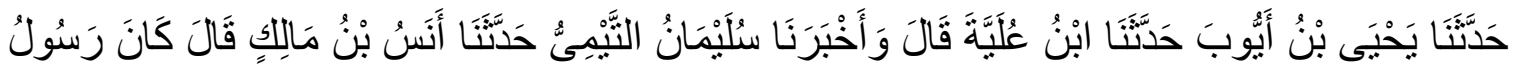

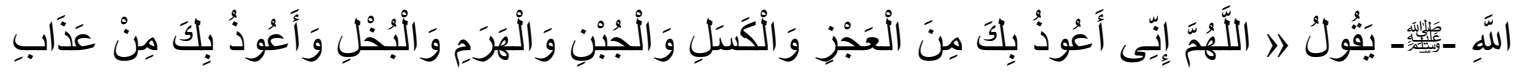

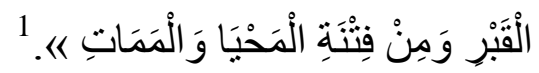

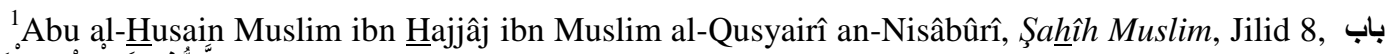
, Nomor 7048, (Beirut: Dâr al-Jîl, tt.), h. 75
} 
Artinya:

Memberitakan kepada kami Yahyâ ibn Ayyûb dari ibn 'Ulaiyah ia berkata memberitakan kepada kami Sulaimân al-Taimiy dari Anas ibn Mâlik ia berkata: Rasulullah saw. bersabda: "Ya Allah! Aku berlindung kepada-Mu dari kelemahan, kemalasan, sifat pengecut, menyia-nyiakan usia dan dari sifat kikir. Aku juga berlindung kepada-Mu dari siksa kubur dan dari fitnah kehidupan serta kematian.

Dengan demikian jelas bahwa sumber utama ajaran Islam yang memuat hal-hal yang berkaitan dengan eksistensi manusia secara fisikal, psikologikal, spiritual, dan sosial turut berperan dalam memicu lahirnya kajian psikologi dalam Islam.

$\underline{\text { Kedua, }}$ dilatarbelakangi oleh kajian tentang akhlak dan tasawuf dan berbagai kajian yang berkaitan dengan upaya membangun kesehatan mental manusia, membuat para ilmuwan Islam kelasik melakukan kajian mendalam tentang jiwa dengan fokus

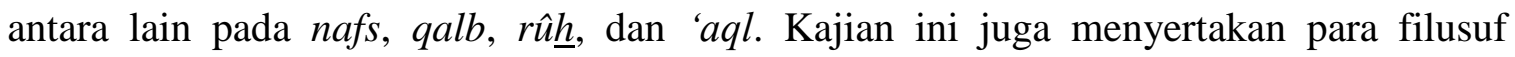
Muslim yang membahas rûh dan nafs dengan mengadopsi kajian roh dari filsafat Yunani. Selama lebih kurang tujuh abad psikologi dibahas dalam kajian filsafat dan tasawuf. ${ }^{2}$

\section{Diskursus Paradigma Psikologi dalam Perspektif Islam}

Menurut Freidrichs Robert paradigma adalah "suatu pandangan mendasar dari suatu disiplin ilmu tentang apa yang menjadi pokok persoalannya."3 Dengan demikian paradigma psikologi secara umum adalah prilaku manusia dan faktor-faktor yang memicu prilaku tersebut. Di dalam Islam, manusia diciptakan dengan fungsi yang tidak hanya terbatas untuk menata kehidupan manusia, ia juga memiliki fungsi sebagai hamba Allah dan juga khalifah Allah. Sebagaimana terdapat dalam Firman Allah berikut ini:

Terjemahnya:

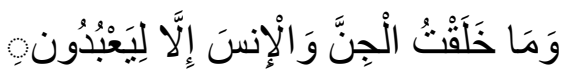

Dan Aku tidak menciptakan jin dan manusia melainkan supaya mereka menyembah-Ku. (QS. 51/al-Dzariyat: 56)

Sebagai hamba manusia harus menjalin hubungan dengan Allah dan menujukan semua aktivitas jasmani dan rohaninya hanya pada Allah.

\footnotetext{
${ }^{2}$ Achmad Mubarok, Jiwa dalam Al-Qur'an, (Jakarta: Paramadina, 2000), h. 261.

${ }^{3}$ Ali Mudhafir, Kamus Istilah Filsafat, (Yogyakarta: Liberty, 1992), h. 114 dikutip oleh Baharuddin, Paradigma Psikologi Islam, (Yogyakarta: Pustaka Pelajar, 2007), 341.
} 


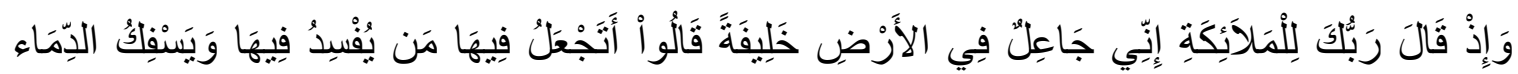

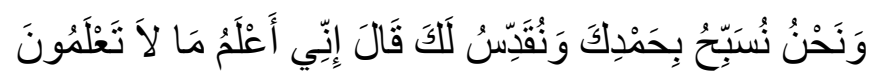

Artinya:

Ingatlah ketika Tuhanmu berfirman kepada para malaikat: "Sesungguhnya Aku hendak menjadikan seorang khalifah di muka bumi". Mereka berkata: "Mengapa Engkau hendak menjadikan (khalifah) di bumi itu orang yang akan membuat kerusakan padanya dan menumpahkan darah, padahal kami senantiasa bertasbih dengan memuji Engkau dan mensucikan Engkau?" Tuhan berfirman: "Sesungguhnya Aku mengetahui apa yang tidak kamu ketahui". (QS. 2/al-Baqarah: 30)

Sebagai khalifah di bumi manusia harus menata kehidupannya dengan sesama manusia dan semua makhluk Allah yang lain termasuk alam raya.

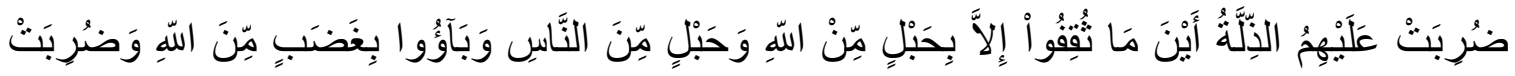

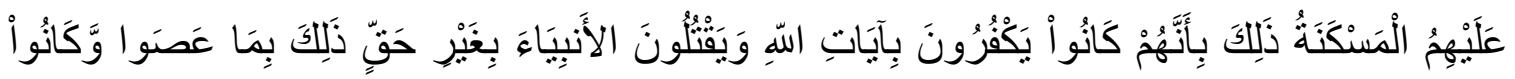
يَعْنَدُونَ

Terjemahnya:

Mereka diliputi kehinaan di mana saja mereka berada, kecuali jika mereka berpegang kepada tali (agama) Allah dan tali (perjanjian) dengan manusia, dan mereka kembali mendapat kemurkaan dari Allah dan mereka diliputi kerendahan. Yang demikian itu karena mereka kafir kepada ayat-ayat Allah dan membunuh para nabi tanpa alasan yang benar. Yang demikian itu disebabkan mereka durhaka dan melampaui batas. (QS. 3/Ali Imran: 112)

Kedua fungsi di atas harus dilakukan sesuai dengan hukum-hukum Allah yang telah Ia tetapkan dalam alam dunia ini. Oleh sebab itu mengkaji hukum-hukum Allah tersebut merupakan kemutlakan jika manusia ingin berhasil menata kehidupannya dan kehidupan alam semesta.

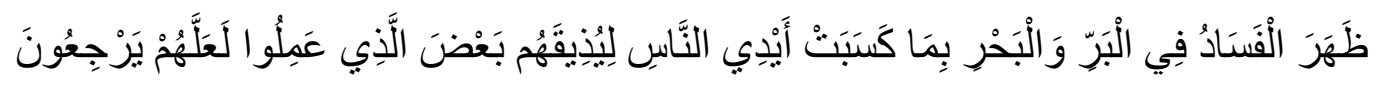

Terjemahnya:

Telah nampak kerusakan di darat dan di laut disebabkan karena perbuatan tangan manusia, supaya Allah merasakan kepada mereka sebahagian dari (akibat) perbuatan mereka, agar mereka kembali (ke jalan yang benar). (QS. 30/al-Rûm: 41)

Dengan demikian yang menjadi pokok persoalan psikologi dalam padangan Islam adalah keselarasan hubungan manusia dengan Tuhannya, sesama manusia, dan alam raya. 
Paradigma psikologi dalam perspektif Islam tidak dapat dipisahkan dari cara manusia mengkaji psikologi itu sendiri. Dari perspektif Islam, manusia dianugerahi tiga alat dalam mencari ilmu pengetahuan: panca indera, akal ('aql, lub), dan hati ( $q a l b$, $\left.f u^{\prime} a d\right)$.

Terjemahnya:

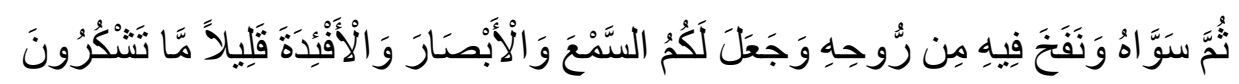

Kemudian Dia menyempurnakan dan meniupkan ke dalam (tubuh) nya roh (ciptaan) -Nya dan Dia menjadikan bagi kamu pendengaran, penglihatan dan hati; (tetapi) kamu sedikit sekali bersyukur. (QS. 32/al-Sajadah: 9)

Tiga alat ini memiliki metode sendiri dalam mendapatkan ilmu pengetahuan. Panca indera mengharuskan penggunaan alat-alat indera untuk mendapatkan ilmu pengetahuan dengan metode observasi, penelitian dan eksperimen empiris dan bergantung pada pengalaman aktual yang tujuannya adalah menemukan pengetahuan di balik fenomena alam (al-ayât al-kauniyah). Diantara ayat yang memotivasi manusia untuk menggunakan penginderaan dalam mendapatkan ilmu pengetahuan adalah:

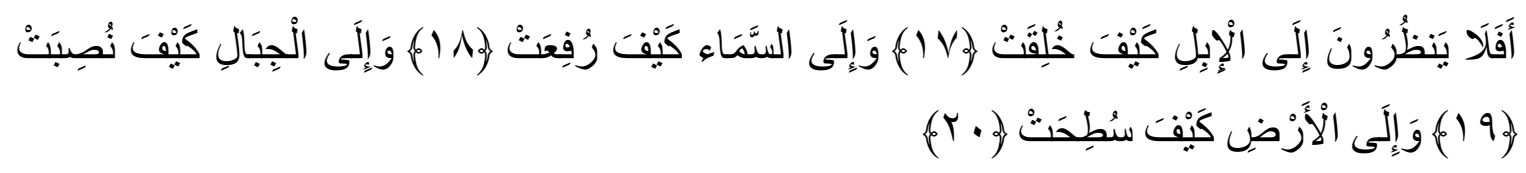

Terjemahnya:

Maka apakah mereka tidak memperhatikan unta bagaimana dia diciptakan $\odot$ Dan langit, bagaimana ia ditinggikan? $\odot$ Dan gunung-gunung bagaimana ia ditegakkan? $\odot$ Dan bumi bagaimana ia dihamparkan? (QS. 88/al-Ghâsyiyah: 1720)

Karena alat-alat indera hanya mampu menangkap hal-hal yang empirik maka hasil pengetahuan yang diperoleh juga terbatas pada hal-hal yang empirik. Itulah sebabnya kajian psikologi pada tingkat ini hanya dapat dilakukan dengan mengkaji prilaku-prilaku manusia sebagai perwujudan dari gejala-gejala jiwanya.

Akal digunakan dalam proses penalaran untuk memilih, mengklasifikasi, memutuskan dan melakukan penalaran serta menangkap realitas dan supra-realitas melalui nalar dengan kemampuan argumentasi logisnya yang kemudian menghasilkan serangkaian hukum dan prinsip yang menjadi bangunan ilmu pengetahuan. Diantara ayat yang menganjurkan hal ini adalah: 


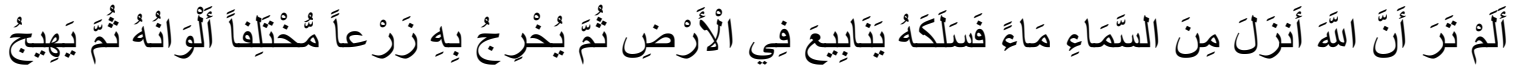

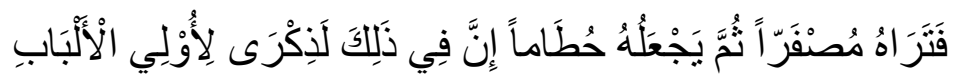

Terjemahnya:

Apakah kamu tidak memperhatikan, bahwa sesungguhnya Allah menurunkan air dari langit, maka diaturnya menjadi sumber-sumber air di bumi kemudian ditumbuhkan-Nya dengan air itu tanam-tanaman yang bermacam-macam warnanya, lalu ia menjadi kering lalu kamu melihatnya kekuning-kuningan, kemudian dijadikan-Nya hancur berderaiderai. Sesungguhnya pada yang demikian itu benar-benar terdapat pelajaran bagi orangorang yang mempunyai akal. (QS. 39/al-Zumar: 21)

Proses penemuan akan supra-realitas ini dilakukan "secara silogistik, yakni menarik kesimpulan tentang hal-hal yang tidak diketahui (the unknown) dari hal-hal yang diketahui (the known)". ${ }^{4}$

Hati dengan metode intuitif ('irfân) melalui pengalaman spiritual-transendental dan potensi batin serta keimanan mampu menangkap hal-hal yang metafisik. ${ }^{5}$ Meskipun akal dan hati mampu menangkap hal-hal yang metafisik keduanya memiliki metode yang berbeda dalam melakukannya. "akal menangkapnya secara inferensial, hati menangkap objek-objek tersebut secara langsung (perensial), sehingga mampu melintasi jurang yang menganga lebar antara subjek dan objek". ${ }^{6}$ Pengetauan yang diperoleh hati wujud dan kebenarannya bersifat spiritual transendental ('ilmu ladunni, 'ilmu hudhuri) yang sangat bergantung pada keridhaan dan bimbingan Ilâhiah, baik dalam bentuk instink, intuisi, inspirasi, ilham, dan wahyu dalam kasus para Nabi dan Rasul. Ilmu-ilmu yang lahir dari proses ketiga ini disebut sebagai perennial knowledge yang lahir sebagai proses unlearning.

Dari berbagai karya-karya psikologi Islam Muhammad Izuddin Taufiq mengklasifikasikan kajian kejiwaan kelasik Islam dalam dua kategori. Pertama, paradigma yang mengkaji defenisi dan teori kejiwaan dalam Alqur'an dan Hadis dengan berbagai topik dan terminologinya. Salah satu produk dalam kategori ini adalah $\mathrm{Al}$ Qur'ân wa 'Ilm al-Nafs dan Al- $\underline{\text { Hadits }}$ wa 'Ilm al-Nafs karya Utsman Najati. Kedua, paradigma yang mengkaji defenisi dan teori kejiwaan dalam kitab-kitab kelasik Islam

\footnotetext{
${ }^{4}$ Mulyadhi Kartanegara, Mengislamkan Nalar: Sebuah Respon Terhadap Modernitas, (Jakarta: Erlanga, 2007), h. 8.

${ }_{5}$ Mulyadhi Kartanegara, Mengislamkan, h. 8.

${ }^{6}$ Mulyadhi Kartanegara, Mengislamkan, h. 8.
} 
dengan berbagai topik dan terminologinya. Salah satu produk kategori ini adalah Dalil alBahitsin Ilâ Mafâhim Nafsiyah fî al-Turats (Petunjuk Bagi Para Peneliti Bagi Memahami Masalah Kejiwaan Dalam Kitab-Kitab Kelasik) hasil kerja sama antara Lajnah 'Ilmiah dengan al-Ma'had al-`Alamiy lî al-Fikr al-Islamiy.

\section{TOKOH, TEORI DAN KARYANYA}

Dalam bidang psikologi pengobatan, ilmuwan-ilmuwan Islam kelasik menekankan keharusan bagi individu untuk memahami kesehatan mental mereka. Rumah sakit yang menangani pasien-pasien dengan keluhan psikhiatri pertama kali dibangun oleh kalangan Muslim di Baghdad pada tahun 705 M, di Fes di awal abad ke 8, di Kairo pada tahun $800 \mathrm{M}$, di Damaskus dan Aleppo pada tahun $1270 \mathrm{M}^{7}$ Para ilmuwan psikologi pada masa kelasik dan pertengahan Islam mendasarkan teori mereka pada psikhiatri klinis dan observasi klinis. Mereka telah membuat kemajuan yang berarti dalam psikhiatri dan merupakan kalangan yang pertama mengaplikasikan psikhoterapi dan penyembuhan moral bagi pasien yang menderita penyakit mental disamping bentuk terapi lainnya seperti mendi, penggunaan obat-obatan, terapi musik.

Konsep kesehatan mental dan kesegaran mental dikenalkan oleh seorang dokter, Ahmad ibn Sahl al-Balkhi (850-934 M) dalam kitabnya Masalih al-Abdan wa al-Anfus ${ }^{8}$ (Keseimbangan Raga dan Jiwa) - yang manuskripnya disimpan di Ayasofya Library, Istanbul dengan nomor 3741 - dengan sukses menjabarkan penyakit-penyakit yang berhubungan dengan jiwa dan raga (psikhosomatis) yang ia istilahkan dengan Tibb alQalb dan al-Tibb al-Ruhani untuk menjabarkan penyakit-penyakit kejiwaan dan penyakit-penyakit yang berhubungan kehidupan spiritual. Ia mengkritik para dokter di masanya yang hanya memfokuskan pada penyakit-penyakit fisik dan menafikan kontribusi psikologis pada penyakit-penyakit fisik. Ia mendasarkan teorinya pada Alqur'an dan Hadis yang banyak menyatakan akan kesehatan jiwa dan penyakit-penyakit jiwa. Ia menyatakan bahwa karena manusia terdiri dari jiwa dan raga maka keduanya akan saling mempengaruhi yang dengan demikian manusia tidak akan mencapai

\footnotetext{
${ }^{7}$ Ibrahim B. Syed, "Islamic Medicine: 1000 years ahead of its times", dalam Journal of the Islamic Medical Association, 2002 (2), 2-9, h. 7-8.

${ }^{8}$ Ahmad ibn Sahl al-Balkhi, Masalih al-Abdan wa al-Anfus, (Kuwait: Dar al-Da`wah li al-Nashr wa al-Tawzi`, 1990).
} 
kesehatan sempurna jika tidak tercapai keseimbangan jiwa dan raga (istilah yang digunakannnya untuk ini adalah isytibak) tidak tercapai. Jika raga sakit maka jiwa akan kehilangan banyak energi kognitif dan kemampuan berpikir komprehensifnya yang kemudian akan mempengaruhi kemampuan untuk menikmati kebahagiaan yang diinginkannya di dalam hidupnya. Demikian juga raga tidak akan mampu menikmati kebahagiaan jika jiwa sedang sakit yang kemudian akan mengakibatnya penyakit fisik. Dengan pendapat-pendapatnya tersebut al-Bakhi kemudian dikenal sebagai pencetus psikologi kognitif dan psikologi pengobatan. Ia yang pertama membedakan neurosis dengan psikhosis. Ia mengklasifikasikan neurosis dalam empat kategori penyimpangan emosional: takut, marah dan agresi, depresi dan kesedihan, obsesi.

Berikut ini adalah penjabaran umum teori psikologi yang dikemukakan oleh dua ahli psikologi masa kelasik Islam, yakni Ibnu Sina dan al-Ghazali.

Ibnu Sina ${ }^{9}$ mendefenisikan jiwa sebagai kesempurnaan awal yang dengannya spesies menjadi sempurna sehingga menjadi manusia yang nyata. Ia membagi jiwa manusia dalam tiga bagian, yaitu jiwa nabati, jiwa hewani dan jiwa rasional.

\section{1) Jiwa nabati.}

Jiwa ini mengandung tiga daya, yaitu:

a. Daya nutrisi yang berfungsi untuk mengolah makanan menjadi bentuk tubuh.

b. Daya pertumbuhan yang berfungsi untuk pengolahan makanan yang telah diserap tubuh agar mencapai kesempurnaan pertumbuhan dan perkembangan tubuh.

c. Daya generatif yang merupakan daya untuk pengolahan secara harmonis unsurunsur makanan yang ada dalam tubuh sehingga menghasilkan pertumbuhan dan perkembangan tubuh yang sempurna.

\section{2) Jiwa hewani.}

Jiwa ini terdiri dari dua daya: daya penggerak dan daya persepsi.

a. Daya pengerak yang terbagi atas daya hasrat dan daya motorik.

Daya hasrat yaitu daya yang berfungsi untuk mendorong perealisasian berbagai bentuk khayalan tentang hal-hal yang diinginkan dan tidak diinginkan. Daya ini terdiri dari dua bagian:

\footnotetext{
${ }^{9}$ Nama lengkapnya adalah Abu 'Alî bin 'Abdullah bin Hasan bin 'Alî bin Sina ( 80 - 1037 M). Bagian ini dirangkum dari Muhammad Utsman Najati, Jiwa dalam Pandangan Para Filosof Muslim, terj. Gazi Saloom, (Bandung: Pustaka Hidayah, 2002).
} 
1) Syahwat, merupakan dorongan untuk mencapai sesuatu yang menimbulkan kenikmatan.

2) Emosi, yang merupakan dorongan untuk melawan sesuatu yang membahayakan, merusak dan menggagalkan pencapaian tujuan, atau dengan kata lain dorongan untuk mencapai kemenangan. Dalam hal emosi Ibnu Sina menyatakan bahwa situasi emosional mempengaruhi kondisi jiwa yang kemudian akan mempengaruhi kondisi fisik, baik secara spontan maupun bertahap. Sedangkan tentang urutan pengaruh emosi dan perubahan fisik itu ia menyatakan terdapat dua kemungkinan: fisik berubah lalu melahirkan perubahan emosi atau emosi merubah kondisi fisik.

Daya motorik berfungsi melaksanakan hasrat yang muncul dalam bentuk motorik untuk mencapai tujuan yang diinginkan.

b. Daya persepsi yang terdiri dari dua bagian, yakni

- Indera internal yang terdiri dari:

1) Indera kolektif, yang merupakan akumulasi semua hasil penginderaan eksternal yang menghasilkan pemrosesan secara global.

2) Konsepsi, yang berfungsi untuk menyimpan gambaran hasil indera kolektif dan mempertahankannya walaupun stimulus inderawinya sudah tidak ada.

3) Fantasi, berfungsi untuk mengolah data daya konsepsi, mengklasifikasikannya dan men-diferensiasikannya. Daya fantasi berperan penting dalam mengingat dengan mengolah data parsial menjadi gambaran untuk dikirim ke daya waham. Daya fantasi juga berperan peting dalam berfikir dengan mengolah data parsial menjadi gambaran untuk dikirim ke akal. Tidak kalah pentingnya, daya fantasi juga berperan penting dalam mimpi dengan melakukan peniruan berbagai prilaku untuk memuaskan berbagai dorongan dan hasrat, khusunya yang tidak terrealisir.

4) Waham, berfungsi untuk mempersepsikan berbagai makna parsial non inderawi yang ada pada stimulus inderawi. Dalam hal ini, waham melihat makna parsial dari berbagai bentuk. Misalnya, pemulung melihat puntung 
rokok sebagai sumber uang. Waham juga merupakan wahana terbentuknya ilham.

5) Memori, berfungsi untuk menyimpan semua data yang dihasilkan dalam waham. Dengan demikian, proses mengingat merupakan hasil kerjasama antara daya waham dan fantasi.

- Indera eksternal yang terdiri dari:

1. Indera penglihatan.

2. Indera pendengaran

3. Indera penciuman

4. Indera perabaan

5. Indera pengecapan

\section{3) Jiwa rasional}

Jiwa rasional merpakan daya khusus yang dimiliki manusia yang fungsinya berhubungan dengan akal. Dari satu sisi jiwa rasional melaksanakan berbagai prilaku berdasarkan hasil kerja pikiran dan kesimpulan ide. Dari sisi lain ia mempersepsi semua persoalan secara universal. Jiwa rasional terdiri dari dua bagian: akal teoritis dan akal praksis.

a. Akal teoritis, yang berfungsi untuk mempersepsi gambaran-gambaran universal yang bebas dari materi.

Akal teoritis terdiri dari lima tingkatan:

3) Akal potensial (materi), memiliki potensi untuk menangkap hal-hal yang rasional.

4) Akal bakat, berfungsi dalam pembenaran premis-premis tanpa melakukan usaha dalam pembenaran itu.

5) Akal aktual, berfungsi untuk mempersepsi hal-hal rasional, dan ini terjadi kapan saja.

6) Akal mustafâd, berfungsi untuk mengolah data akal aktual untuk dimanfaatkan.

7) Akal kudus, yang berfungsi untuk memproses hal-hal yang ada dalam akal aktual secara otomatis (tanpa usaha manusia itu sendiri). Tingkatan ini merupakan tingkatan tertinggi yang umumnya hanya dimiliki oleh para nabi. 
b. Akal praksis, yang berfungsi untuk memproses semua data dari akal teoritis untuk memutuskan pengambilan tindakan.

Al-Ghazaly ${ }^{10}$ sangat mementingkan ilmu jiwa dan memandangnya sebagai jalan untuk mengenal Allah. Teori-teori al-Ghazaly tentang jiwa senada dengan teori Ibnu Sina dan al-Farabi. Ia membagi ilmu jiwa menjadi dua bagian. Pertama, ilmu jiwa yang mengkaji tentang daya hewan, daya jiwa manusia, daya penggerak, dan daya jiwa sensorik. Kedua, ilmu jiwa yang mengkaji tentang pengolahan jiwa, terapi dan perbaikan akhlak.

Berdasarkan kekuatan emosi dan syahwat yang menguasai manusia Al-Ghazaly membagi sifat manusia menjadi empat. Keempat sifat ini merupakan potensi yang dimiliki manusia secara alami (instink) dan dapat dikembangkan dan dikendalikan melalui proses belajar.

1) Sifat hewan buas (as-sab'iyyah) akan muncul dari diri manusia yang dikuasai emosi, dan perwujudannya berupa prilaku permusuhan, kebencian, penyerangan terhadap manusia lain baik melalui perkataan maupun perbuatan.

2) Sifat hewan liar (al-bahîmiyah) akan menjelma jika manusia dikuasai syahwat dengan perwujudannya adalah tingkah laku kejahatan, ketamakan dan seksual.

3) Sifat setan (asy-syaithâniyah) muncul dari perpaduan kekuasaan syahwat dan emosi serta kemampuan membedakan. Wujudnya berupa prilaku kejahatan dan memperlihatkan kejahatan dalam bentuk kebaikan.

4) Sifat ketuhanan (ar-rabbâniyah), yang bila menguasai manusia akan melahirkan pribadi yang bertindak seperti Tuhan, seperti: sangat cinta kekuasaan, kebesaran, kekhususan, kediktatoran, lepas dari peribadatan, sombong, mengakui dirinya berilmu sangat luas.

Tentang daya fantasi al-Ghazaly menyatakan bahwa manusia berbeda dalam kadar dan kesiapannya. Kualitas daya fantasi ini akan mempengaruhi hubungannya dengan Akal Aktif. Sebagian orang memiliki daya fantasi sangat kuat, sehingga proses pengolahan data ke jiwa rasional tidak bergantung pada input dari daya indera.

\footnotetext{
${ }^{10}$ Nama lengkapnya adalah Abu Hamid Muhammad bin Muhammad al-Ghazaly (1058 - $\left.1111 \mathrm{M}\right)$. Bagian ini dirangkum dari Muhammad Utsman Najati, Jiwa dalam Pandangan Para Filosof Muslim, terj. Gazi Saloom, (Bandung: Pustaka Hidayah, 2002).
} 
Dalam upaya perolehan pengetahuan manusia menempuh dua cara. Pertama, melalui proses belajar yang bersifat manusiawi dengan menggunakan indera dan akal. Hasilnya adalah perolehan ilmu dan keahlian inderawi. Pengetahuan jenis ini adalah pengetahuan yang terbatas dan tidak memiliki keterkaitan dengan alam ghaib, apalagi dengan Allah. Kedua, melalui belajar secara rabbâni atau belajar ladunnî yang hasilnya adalah pengungkapan pengetahuan hati secara langsung melalui ilham dan wahyu. Jenis pengetahuan rabbâni ini merupakan tingkat tertinggi pengetahuan. Untuk memperoleh pengetahuan jenis ini diperlukan ibadah, kejuhudan, pendekatan diri kepada Allah (mujâhadah), pengolahan batin (riyâdah an-nafs) menuju akhlak mulia. Orang yang telah berhasil menguasai pengetahuan secara rabbâni akan memperoleh ketenangan, kebahagiaan dan kenikmatan pengetahuan sejati.

Demikian juga Najab al-Dîn Muhammad (abad 10) memaparkan berbagai penyakit mental secara rinci berdasarkan pengamatan yang teliti terhadap pasien-pasien yang mengidap penyakit mental. Hasil pengamatannya ini kemudian dikompilasikannya dengan mengklasifikasikan berbagai penyakit mental sehingga kompilasinya tersebut merupakan pengklasifikasian terlengkap hingga saat itu dan digunakan hingga saat ini. Tokoh lainnya adalah Muhammad ibn Zakarīya Rāzi (Rhazes), seorang bangsa Persia dan penganut agama Zoroaster dengan karyanya al-Mansuri dan al-Hawi yang diterbitkan pada aban ke 10 dan memuat antara lain defenisi penyakit jiwa, simpomnya, dan penyembuhannya. Ia juga mengepalai rumah sakit jiwa di Baghdad sesuatu yang tidak dimiliki oleh bangsa-bangsa Eropah. ${ }^{11}$ Di bagian lain kawasan Islam, yakni di Andalusia dikenal Abu al-Qasim (Abulcasis) yang dikenal sebagai bapak ilmu bedah, juga Ibn Zuhr (Avenzoar) yang pertama kali memberikan deskripsi yang akurat tentang penyimpangan neorologis.

Ibn al-Haytham dikenal sebagai penemu psikologi eksperimental dan pskhofisik dalam kitabnya Kitab al-'Ain. Demikian juga al-Kindi yang dikenal sebagai perintis psikologi eksperimental yang secara empiris memperkenalkan waktu reaksi antara organorgan sensoris, stimulasi organ dan kesadaran persepsi dalam pengobatan. Ibn Sina dikenal sebagai perintis psykhofisiologi dan pengobatan psikhosomatis yang

\footnotetext{
${ }^{11}$ Ibrahim B. Syed PhD, "Islamic Medicine: 1000 Years Ahead of Its Times", dalam Journal of the Islamic Medical Association, 2002 (2), 2-9, h. 7.
} 
memperkenalkan antara lain halusinasi, insomnia, mania, mimpi buruk, melankolis, epilepsi, paralisis, stroke, vertigo dan tremor.

Pada masa kontemporer dalam bidang teoritis beberapa pakar Psikologi maupun pencinta Psikologi Islam telah melahirkan karya-karya dalam bidang ini, yang antara lain:

1) Adnan Syarif. Menurut Adnan Syarif banyak di kalangan masyarakat dan bahkan di kalangan pemerhati Psikologi masih mencampuradukkan antara jasad, nafs dan ruh, serta lebih khusus lagi antara jiwa dengan ruh. Ia berpendapat bahwa nafs adalah darah yang merupakan sumber segala gejala yang dimunculkan oleh anggota tubuh dan jiwa. ${ }^{12}$ Ruh merupakan substansi yang menjadi pengerak pertama bagi segala kehidupan. Ruh berpusat di dalam dada dan hati yang kemudian menyebar ke seluruh tubuh melalui darah. Qalb yang ditempati ruh dan mengandung berbagai rahasia Ilahi berfungsi sebagai stasiun transmisi, sedangkan otak berfungsi sebagai layar penerima yang kemudian meneruskannya ke seluruh tubuh. Itulah sebabnya jika qalb rusak maka entitas lain juga akan mengalami kerusakan. Pemeliharaan qalb merupakan keharusan, sebab jika qalb terpelihara akan menghasilkan ruh yang bersih, jiwa yang tenang, emosi dan semua yang direfleksikannya akan menjadi lurus, suci, dan terhindar dari berbagai penyakit. Siklus ini harus disadari oleh setiap ahli Psikologi, sebab tanpa penetahuan akan siklus ini maka terapi psikologis tidak akan berhasil secara sempurna. Salah satu karyanya adalah Min 'Ilm an-Nafs al-Qurânî yang diterbitkan di Beirut oleh Dâr al-'Ilm li al-Malâyîn pada tahun 1987.

2) Mohammad Shafii. Muhammad Shafii adalah seorang profesor psikhiater dan psikhiater anak di Universitas Louisville School of Medicine. Ia mendapatka gelar M.D dari Universitas Tehran Medical School, kemudian menerima pelatihan tingkat lanjut dalam bidang psikhiater dan psikhiater anak di Neuropsychiatric Institute dan Children's Psychiatric Hospital di Universitas Michigan Medical Center. Selama lebih dari empat puluh tahun ia mendalami dan meneliti dan mengkaji studi komparasi psikhoterapi dan perkembangan manusia dari perspektif Barat dan Timur. Karya-karyanya terfokus dalam bidang psikhoanalisa, psikhodinamis, dan signifikansi psikhoterapi dengan tehnik meditasi termasuk sufisme. Salah satu

\footnotetext{
${ }^{12}$ Adnan Syarif, Min 'Ilm an-Nafs al-Qurânî, (Beirut: Dâr al-'Ilm li al-Malâyîn, 1987) edisi terjemahan dalam Bahasa Indonesia oleh Muhammad Ali Mighwar, Psikologi Qurani (Bandung: Pustaka Hidayah, 2002), 57.
} 
karyanya adalah, Freedom from the Self: Sufism, Meditation and Psychotherapy, yang diterbitkan di New York oleh Human Science Press pada tahun 1988.

3) Abdul Mujib dan Jusuf Mudzakir, Nuansa-nuansa Psikologi Islam, Jakarta: Rajawali, 2001.

4) Dadang Hawari, Al-Qur'an, Ilmu Kedokteran Jiwa dan Kesehatan Jiwa, Jakarta: Dhana Bhakti Prima Yasa, 1996.

5) Fuad Nashori (ed.), Membangun Paradigma Psikologi Islam, Yogyakarta: Sipress, 1994.

6) Hanna Djumhana Bastaman, Integrasi Psikologi dengan Islam: Menuju Psikologi Islam, Yogyakarta: Pustaka Pelajar, 1997.

7) M. Thoyini dan M. Ngemron (ed)., Psikologi Islam, Surakarta: Muhammadiyah University Press, 1996.

8) Malik B. Badri, The Dilemma of Muslim Psichologists, terj. Siti Zainab Luxfiati, Jakarta: Pustaka Firdaus, 1996.

9) M. Yasir Nasution, Manusia Menurut al-Ghazaly, Jakarta: Rajawali, 1988.

10) Rendra K. (ed), Metodologi Psikologi Islam, Yogyakarta: Pustaka Pelajar, 2000.

11) Sukanto dan A. Dardiri Hasyim, Nafsiologi, Surabaya: Risalah Gusti, 1996.

12) Sukanto dan A. Dardiri Hasyim, Nafsiologi, Surabaya: Risalah Gusti, 1996.

13) Yahya Jaya, Spritualisasi Islam dalam Menumbuhkembangkan Kepribadian dan Kesehatan Mental, Jakarta: Ruhama, 1994.

14) Hasan Langgulung, Manusia dan Pendidikan: Suatu Analisa Psikologi dan Pendidikan, Jakarta: Pustaka Al-Husna, 1986.

\section{IMPLIKASI BAGI DUNIA ISLAM}

Kesuksesan ilmuwan-ilmuwan Muslim kelasik dan abad pertengahan memadukan ajaran-ajaran dan nilai-nilai Islam dalam berbagai bidang, termasuk psikologi, tidak mampu diikuti oleh ilmuwan-ilmuwan Muslim kontemporer. Entah apa sebabnya, tibatiba ilmuwan-ilmuwan Muslim kontemporer terputus dari khazanah keilmuwan kelasik dan lebih parah lagi tercabut dari akar keislamannya.

Praktek-praktek terapi dan pembangunan mental dan psikologi yang mengakar pada kultur Islam dalam dunia Islam kontemporer lebih banyak diambil alih oleh 
tasawuf. Sehingga praktek tasawuf kemudian berkembang bahkan sampai pada belahan dunia yang maju dan non Islam seperti Amerika. Fenomena ini kemudian melahirkan kajian-kajian psikologis dalam dunia tasawuf. Salah satu tokoh yang sangat mengemuka dalam hal ini adalah Inayat Khan dengan salah satu karyanya Spiritual Dimension of Psychology.

Kondisi ini kemudian disadari pada beberapa dekade belakangan ini sehingga menimbulkan geraka islamisasi sains dan tehnologi. Dalam bidang psikologi tentu saja islamisasi ini tidak terelakkan, sebab konsep psikologi yang saat ini ada gagal membicarakan manusia secara totalitas. Kegagalan ini berupa pengkajian terfokus pada manifestasi gejala jiwa (tingkah laku) dan bukan jiwa itu sendiri, penafian unsur-unsur spiritual manusia, dan dibangun atas dasar penafsiran fakta ilmiah sedangkan fakta ilmiah tidak selalu sesuai dengan teori dan selalu dipengaruhi bias kepribadian dan budaya pembangunnya. Para ahli psikologi Muslim dan para pencinta psikologi Islam akhirnya aktif memunculkan Psikologi Islam dalam dunia psikologi.

Untuk mewujudkan Psikologi Islam ini setidaknya ada empat tahap yang harus ditempuh: Pertama, melakukan reskonstruksi sistematis terhadap Psikologi agar dapat melahirkan konsep yang mengintegrasikan ketauhidan dengan seluruh aspek kehidupan manusia yakni: sejarah, pengetahuan, metafisika, etika, tata sosial, ummah, keluarga, tata politik, tata ekonomi, tata dunia dan estetika. Proses islamisasi Psikologi ini tentu saja sama dengan proses islamisasi sains dan tehnologi lainnya. Dalam hal ini Ismail Raji alFaruqi menetapkan lima prinsip pokok dan lima sasaran rencana islamisasi.

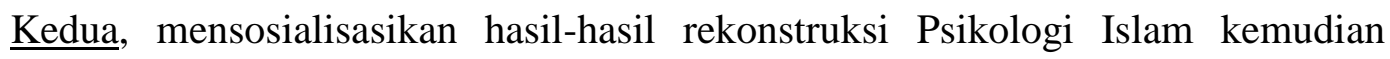
dikembangkan, diperkaya, dilipat gandakan dan yang tidak kalah pentingnya juga harus ditingkatkan dengan memperluas fungsinya sampai kepada dimensi masyarakat secara global.

Ketiga, mengoptimalkan fungsi lembaga-lembaga keilmuan Islam dalam usaha pencapaian pengembangan Psikologi Islam. Termasuk didalamnya mengembangkan budaya ilmiah.

Keempat, membentuk dan menyebarluaskan Psikologi Islam sebagai satu bentuk kebudayaan dan peradaban Islam. Ini merupakan titik akhir dari perjuangan umat Islam terhadap kebudayaan dan peradaban manusia. Tahap ini sangat penting, sebab 
kebudayaan dan peradaban yang sekarang ini terbangun dari gagasan-gagasan yang didasarkan pada asumsi, meredupkan aqidah. Ditambah lagi, penetrasi ideologi-ideologi yang berseberangan dengan Islam yang kemudian ke lahan-lahan intelektualitas Islam, khususnya yang dipaksakan oleh kekuatan-kekuatan non Islam, membentuk keyakinankeyakinan baru yang menyesatkan dan mengaburkan wawasan dan pandangan manusia tentang dirinya, alam semesta dan Allah. Dengan demikian, bangunan peradaban yang berdasarkan konsep Ilahiah perlu dikembangkan agar dapat mengembalikan manusia ke dalam bangunan intelektual keimanan yang hidup atas, dengan dan untuk Allah. ${ }^{13}$ Kegagalan dalam usaha ini akan mengakibatkan kegagalan penyebaran Psikologi Islam dan berarti pula kegagalan menunaikan missi utama Rasulullah Muhammad saw. yang menjadi inti kehidupan manusia, yakni penyempurnaan akhlaq manusia.

\section{KESIMPULAN}

Teori psikologi yang sudah mapan ternyata memiliki keterbatasan-keterbatasan. Keterbatasan itu meliputi dua hal yang mendasar, yaitu objek studinya dan pendekatan ilmiah yang digunakan. Dari sisi objek, manusia dan bagian-bagiannya hanya dimaknai secara material empiris. ${ }^{14}$ Contohnya dalam berpikir psikologi non Islam hanya menitik beratkan pada fungsi otak dengan mengabaikan fungsi-fungsi non fisik seperti qalb dan 'aql. Ini berarti bahwa psikologi non Islam telah melakukan reduksi dan simplifikasi keutuhan realitas eksistensi manusia. Dari sisi metode, psikologi non Islam menggunakan metode introspeksi dan metode ilmu-ilmu alam untuk mengkaji entitas jiwa sehingga lahirlah aliran strukturalis dan aliran behavioris serta psikoanalisis. Kalangan strukturalis mengkaji jiwa melalui introspeksi dan menganalisis kesadaran hingga ke unsur terkecilnya sedangkan kalangan behavioris lebih memfokuskan pada prilaku. Kalangan psikoanalisis menggunakan metode tersendiri yakni asosiasi bebas dalam terapi perilaku. Ketiga aliran ini secara ensensi menggunakan pendekatan yang sama, yakni metode ilmiah yang ketat sebagaimana yang diterapkan pada ilmu-ilmu alam. Hasilnya adalah, 194-200.

${ }^{13}$ Syed Habibul Haq Nadvi, The Dynamics of Islam, terj. Asep Hikmat, (Bandung: Risalah, 1982),

${ }^{14}$ M. Thoyibi dan M. Ngemron (ed)., Psikologi Islam (Surakarta: Muhammadiyah University Press, 1996), h. v. 
psikologi menghadapi kesulitan dalam menjelaskan fakta-fakta yang berkaitan dengan keutuhan eksistensi manusia, terutama yang berhubungan dengan pengalamanpengalaman spiritual.

Keterbatasan-keterbatasan tersebut menghalangi para ahli psikologi untuk mengungkap realitas eksistensi manusia secara utuh. Oleh sebab itu, diperlukan pendekatan alternatif untuk keluar dari kungkungan keilmiahan konvensional dengan mengambil pendekatan yang lebih luas yang mampu mengungkapkan pengalamanpengalaman fisikal, psikologikal, sosial dan spiritual manusia secara integral. Dan psikologi Islam tampaknya merupakan satu-satunya pilihan.

Dari paparan di atas dapat disimpulkan bahwa dengan menelusuri karya-karya kelasik Islam jelas diketahui bahwa para ilmuwan Muslim terdahulu telah membangun dasar-dasar dan pengembangan Psikologi yang dengan itu tidak diragukan lagi bahwa sesungguhnya mereka memiliki andil yang sangat besar dalam mengembangkan kajian tentang kejiwaan. Ironisnya, berbeda dengan bidang filsafat, kedokteran dan sains, peranan mereka dalam memajukan dan mengembangkan psikologi tersebut idak mendapatkan perhatian yang layak dari para pakar sejarah psikologi modern, khususnya dari kalangan Muslim, sepanjang sejarah.

Menyadari keunggulan perkembangan pemikiran dan praktek psikologis pada masa Islam kelasik dan pertengahan yang menyatu dalam filsafat, tasawuf dan akhlaq, maka merupakan hal urgen bagi umat Islam, khususnya tokoh-tokoh dan pecinta psikologi untuk kembali membangun teori dan aplikasi psikologi Islam yang mandiri. Pada saat ini dari sisi praksis, therapy psikologis holistik islami telah dilakukan oleh berbagai kalangan, misalnya therapy psikologis melalui ibadah (antara lain dengan zikir). Maka optimisme muncul untuk dapat membaku praktek-praktek tersebut dalam bangunan keilmuwan psikologi yang mandiri.

Perkembagan pemikiran psikologi dalam dunia Islam kontemporer dilatar belakangi oleh gerakan islamisasi sains dan teknologi. Gelombang ini melanda seluruh wilayah Muslim termasuk Indonesia. Khusus di Indonesia, beberapa dekade terakhir ini di kalangan psikolog Muslim Indonesia muncul diskursus tentang psikologi Islam. Kemunculan diskursus psikologi Islam ini dapat dipandang dari dua sisi. Di satu sisi, ini merupakan indikasi pengaruh gelombang dan semangat Islamisasi sains dan teknologi 
yang telah mulai merebak sejak tahun 1980-an. Di sisi lain, ini merupakan refleksi dari kesadaran sebagian psikolog Muslim Indonesia yang mulai memahami keterbatasanketerbatasan psikologi dalam menjelaskan realitas eksistensi manusia secara paripurna. Antusiasme terhadap kemunculan Psikologi Islam mendorong terselenggaranya berbagai simposium, seminar, dan penerbitan buku tentang psikologi Islam. Namun gerakangerakan ini masih bersifat periferial, walaupun perlu diakui bahwa diskursus-diskursus ini telah mengarah kepada persoalan-persoalan mendasar, atau dengan kata lain, sebagian psikolog Muslim Indonesia mulai menyadari secara sungguh-sungguh keterbatasan teoriteori psikologi yang sudah mapan dalam mengungkapkan eksistensi manusia sesungguhnya. Dengan demikian perlu melakukan kajian alternatif dalam membahas tentang manusia.

Untuk mewujudkan hal ini tentu saja bukanlah hal yang mustahil walaupun bukan berarti tanpa kendala. Beberapa faktor penghambatnya yang paling utama adalah sikap psikolog Muslim yang tidak seragam, yakni : apatis, fanatis, sekularis, antagonis dan idealis. Faktor penghambat lainnya adalah keterpesonaan sebagian psikolog Muslim dengan teori-teori yang telah mapan dan berkembang yang tidak berasal dari Islam.

Selain hambatan di atas, ada sejumlah problem yang dihadapi dalam pengembangan Psikologi Islam, antara lain:

1) Belum ada teori Psikologi Islam yang mapan, atau setidak-tidaknya belum tergali konsep-konsep mendetail yang dapat dijadikan landasan teoritis untuk menjelaskan berbagai fenomena kemanusiaan secara islami.

2) Para ilmuwan Islam, khususnya yang mendalami bidang Psikologi, kurang atau tidak menguasai bahasa arab dan bahasa-bahasa dunia Islam yang berkaitan dengan karyakarya kelasik Islam.

3) Para ilmuwan Islam kurang atau tidak memiliki akses sama sekali dalam merujuk karya-karya Islam klasik.

4) Kekurangan atau ketiadaan penelitian Psikologi Islam yang mandiri.

5) Kelangkaan jaringan dan wadah bagi psikolog Muslim.

Segala hambatan dan tantangan dalam pembangunan kembali dan pengembangan Psikologi Islam memerlukan kesatuan dan kebersamaan semua lapisan umat Islam untuk saling bahu-membahu dalam mewujudkan psikologi Islam. Kemudian umat Islam harus 
memperlakukan semua kesulitan dalam mewujudkan dan mengembangkan Psikologi Islam bukan sebagai hambatan melainkan sebagai tantangan yang perlu ditaklukkan.

\section{DAFTAR PUSTAKA}

"Ahmed ibn Sahl al-Balkhi" http://en.wikipedia.org/wiki/Ahmed_ibn_Sahl_alBalkhi.htm diakses tanggal 20 Nopember 2011.

"Medicine in medieval Islam" http://en.wikipedia.org/wiki/Islamic_medicine.htm diakses tanggal 20 Nopember 2011.

Al-Balkhi, Ahmad ibn Sahl. (1990). Masalih al-Abdan wa al-Anfus, Kuwait: Dar alDa`wah li al-Nashr wa al-Tawzi'.

Al-Faaruqi, Isma'il Raji, (1988). Tawhid: Its Implication for Thought and Life, terj. Rahmani Astuti, Bandung: Pustaka.

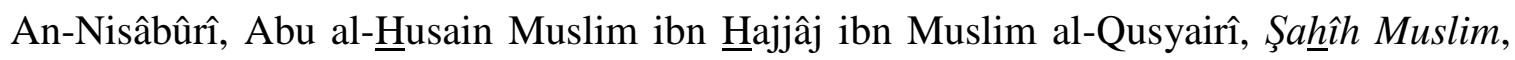
Beirut: Dâr al-Jîl, tt.

Baharuddin. Paradigma Psikologi Islam. (2007).Yogyakarta: Pustaka Pelajar, 2007.

Bastaman, Hanna Djumhana. (1997). Integrasi Psikologi dengan Islam: Menuju Psikologi Islam, Yogyakarta: Pustaka Pelajar.

Deuraseh, Nurdeen, "Physical Medicine and Spiritual Medicine in Islam: An Interweaving" dalam The Yale Journal for Humanities in Medicine di http://info.med.yale.edu/intmed/hummed/yjhm/essays/ndeuraseh3.htm diakses tanggal 20 Nopember 2011.

Ibn Khaldun. (2000). Muqaddimah, terj. Ahmadie Thoha, Jakarta: Pustaka Firdaus.

Kartanegara, Mulyadhi. (2007). Mengislamkan Nalar: Sebuah Respon Terhadap Modernitas, Jakarta: Erlanga.

Khaleefa, Omar. "Who Is the Founder of Psychophysics and Experimental Psychology?" dalam American Journal of Islamic Social Sciences, Summer 1999, 16 (2).

Martin-Araguz, A.; Bustamante-Martinez, C.; Fernandez-Armayor, Ajo V.; MorenoMartinez, J. M.. "Neuroscience in al-Andalus and its influence on medieval scholastic medicine", dalam Revista de neurología, 2002, 34 (9).

Mubarok, Achmad. (2000). Jiwa dalam Al-Qur'an, Jakarta: Paramadina, 2000.

Mudhafir, Ali. (1992). Kamus Istilah Filsafat, Yogyakarta: Liberty, 1992.

Mujib, Abdul dan Jusuf Mudzakir. (2001). Nuansa-nuansa Psikologi Islam, Jakarta: Rajawali.

Nadvi, Syed Habibul Haq. (1982). The Dynamics of Islam, terj. Asep Hikmat, Bandung: Risalah.

Najati, Muhammad Utsman. (2002). Jiwa dalam Pandangan Para Filosof Muslim, terj. Gazi Saloom, Bandung: Pustaka Hidayah. 
Syed, Ibrahim B., "Islamic Medicine: 1000 years ahead of its times", dalam Journal of the Islamic Medical Association, 2002, (2), h. 2-9.

Thoyibi, M. dan M. Ngemron ed. (1996). Psikologi Islam, Surakarta: Muhammadiyah University Press. 
